\title{
Garnet-biotite diffusion mechanisms in complex high-grade orogenic belts: Understanding and constraining petrological cooling rates in granulites from Ribeira Fold Belt (SE Brazil)
}

\author{
Telmo M. Bento dos Santos a, b, *, Colombo C.G. Tassinari ${ }^{\mathrm{c}}$, Paulo E. Fonseca ${ }^{\mathrm{b}}$ \\ ${ }^{a}$ LNEG - Laboratório Nacional de Energia e Geologia, Apartado 7586, 2610-999 Amadora, Portugal \\ b CeGUL - Centro de Geologia, Universidade de Lisboa, 1749-016 Lisboa, Portugal \\ ${ }^{c}$ IEE-USP - Instituto de Energia e Ambiente, Universidade de São Paulo, Rua do Lago, 562, CEP: 05508-080 São Paulo, Brazil
}

\section{A R T I C L E I N F O}

Article history:

Received 11 April 2014

Accepted 2 September 2014

Available online 16 September 2014

\section{Keywords:}

Petrological cooling rates

Garnet-biotite $\mathrm{Fe}-\mathrm{Mg}$ diffusion

Thermal modelling

Ribeira Fold Belt

Thermochronology

\begin{abstract}
A B S T R A C T
Cooling rates based on the retrograde diffusion of $\mathrm{Fe}^{2+}$ and $\mathrm{Mg}$ between garnet and biotite inclusions commonly show two contrasting scenarios: a) narrow closure temperature range with apparent absence of retrograde diffusion; or b) high result dispersion due to compositional variations in garnet and biotite. Cooling rates from migmatites, felsic and mafic granulites from Ribeira Fold Belt (SE Brazil) also show these two scenarios. Although the former can be explained by very fast cooling, the latter is often the result of open-system behaviour caused by deformation. Retrogressive cooling during the exhumation of granulite-facies rocks is often processed by thrusting and shearing which may cause plastic deformation, fractures and cracks in the garnet megablasts, allowing chemical diffusion outside the garnet megablast - biotite inclusion system.

However, a careful use of garnets and biotites with large $\mathrm{Fe} / \mathrm{Mg}$ variation and software that reduces result dispersion provides a good correlation between closure temperatures and the size of biotite inclusions which are mostly due to diffusion and compositional readjustment to thermal evolution during retrogression.

Results show that felsic and mafic granulites have low cooling rates $\left(1-2{ }^{\circ} \mathrm{C} / \mathrm{Ma}\right)$ at higher temperatures and high cooling rates $\left(\sim 100{ }^{\circ} \mathrm{C} / \mathrm{Ma}\right)$ at lower temperatures, suggesting a two-step cooling/exhumation process, whereas migmatites show a small decrease in cooling rates during cooling (from 2.0 to $0.5^{\circ} \mathrm{C} / \mathrm{Ma}$ ). These results agree with previously obtained thermochronological data, which indicates that this method is a valid tool to obtain meaningful petrological cooling rates in complex high-grade orogenic belts, such as the Ribeira Fold Belt.
\end{abstract}

(c) 2014 Elsevier Ltd. All rights reserved.

\section{Introduction}

Petrological cooling rates are cooling rates obtained by the thermal modelling of the diffusive process of two cations (for instance) between two different minerals, whereas geochronological cooling rates are based on the integration of multiple isotopic systems at their respective closure temperature (as in Spear and Parrish, 1996). Seminal works by Dodson (1973) and Lasaga et al. (1977) were the firsts to use mineral diffusion mechanisms to determine cooling rates. The reasoning behind these articles was

\footnotetext{
* Corresponding author. LNEG - Laboratório Nacional de Energia e Geologia, Estrada da Portela, Bairro do Zambujal, Apartado 7586, Alfragide, 2610-999 Amadora, Portugal. Fax: +351214719018.

E-mail addresses: telmo.santos@lneg.pt, tmsantos@fc.ul.pt (T.M. Bento dos Santos)
}

further developed by other authors (e.g.: Ehlers et al., 1994; Spear and Parrish, 1996; Gangully et al., 1998) as the latters assumed that diffusion induced by compositional variations in the garnet-

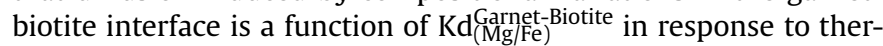
mal changes, such as cooling during retrogression (Fig. 1a). During cooling, garnet is enriched in $\mathrm{Fe} /(\mathrm{Fe}+\mathrm{Mg})$, whereas biotite inclusions become poorer until temperature drops below the closure temperature and diffusion becomes negligible. The diffusive process is limited by the rate of diffusion in garnet, because the diffusion coefficients of Fe and Mg in biotite are substantially higher than in garnet ( $\mathrm{D}_{\mathrm{Fe} / \mathrm{Mg}}^{\text {Bigte }}>>\mathrm{D}_{\mathrm{Fe} / \mathrm{Mg}}^{\mathrm{Gan}}$ ). Because mass balance determines that the rate of cation transfer in the garnet/biotite interface must be the same from garnet to biotite and from biotite to garnet (Fig. 1a), the $\mathrm{Fe} /(\mathrm{Fe}+\mathrm{Mg}$ ) variations will be a function of garnet/biotite proportion or, in this case, biotite inclusion size (Fig. 1b). Therefore, in a closed system where garnet porphyro/ 